\title{
DEVELOPMENT OF INFORMATION SUPPORT OF QUALITY MANAGEMENT OF UNDERGROUND PIPELINES
}

\author{
Larysa Yuzevych \\ Department of Metrology, Standardization and Certification \\ Lviv Polytechnic National University \\ 12 Stepana Bandery str., Lviv, Ukraine, 79013 \\ larysa.yuzevych@gmail.com \\ Ruslan Skrynkovskyy \\ Department of Business Economy and Information Technology \\ Lviv University of Business and Law \\ 99 Kulparkivska str., Lviv, Ukraine, 79021 \\ uanlviv@ukr.net \\ Bohdan Koman \\ Department of System Design \\ Ivan Franko National University of Lviv \\ 1 Universytetska str., Lviv, Ukraine, 79000 \\ sonce_28@ukr.net
}

\begin{abstract}
Recommendations are worked out in relation to the evaluation of longevity and quality of underground metallic pipelines in the conditions of corrosion fatigue. The features of early exposure of crisis (before accident) situations are set. A complex qualimetric criterion is offered for determination of level of quality of pipeline by the account of his technological specific. The elements of investment project and methodology of estimation of resource are worked out and also influences of factors of different nature on risks and possibility of accident of gas pipelines.

The model of corrosion fatigue of metal is based on strength criterion of fracture mechanics according to which there is an act of destruction in an arbitrary elemental volume of a material if the total irreversibly scattered energy of plastic deformation for all load cycles will reach a critical value equal to the energy of destruction.

In order to control the corrosion process taking the polarization potential into account, a criterion relation is used to determine the rate of residual corrosion of a metal in the defect of the insulation coating, in particular, at the top of the crack, which is an anode region.

The adhesive strength criteria of biocorrosive aggressive soil, mechanical criteria for the stress intensity factor, the criterion of corrosion resistance defect, criterion correlation for estimating the speed of residual corrosion in defect of insulation coating with imposed diagnostic weight characteristics and diagnostic value of tests, that complement, clarify and improve the corrosion monitoring system of pipelines, helpful for controlling and optimizing of the corrosion process, and Development of recommendations for anti-corrosion protection of metal are used in areas with non-stationary plastic deformation.
\end{abstract}

Keywords: steel pipeline, normative and technical documentation, resource, low-cycle fatigue, corrosion, quality, risks, mechanical loading, investment project.

\section{Introduction}

One of the main problems in the field of industrial safety of facilities and enterprises of the oil and gas complex (OGC) is the shortcomings in the quality of regulatory and technical documentation and the issues of ensuring reliable operation of structural elements. In this area, it is necessary to ensure the improvement of the system of normative and technical documents [1-4]. Let's consider metal underground pipelines (MUPs), in particular, gas pipelines, through which gaseous hydrocarbons are transported. The MUPs destruction is accompanied by economic losses, and also threatens the personnel of the relevant enterprises and the environment.

Ensuring the MUPs project resource is an important task in the operation of modern OGC enterprises. The solution of this problem allows to clarify the choice of materials and design and 
technological solutions, as well as to provide economically efficient operating conditions for OGS. The risks associated with the MUPs operation are associated with defects in metal (steel), which arise as a result of corrosion and cyclic loads. Among the main causes of damage (defects) are called nucleation and propagation of cracks from vibrations, high static and cyclic loads, stress concentrators, corrosion fatigue, cavitation-erosion wear, etc. [4, 5].

Calculations of parameters characterizing the corrosion fatigue and fatigue life of structural elements are labor-intensive processes, since during their implementation the researcher must operate with a large amount of data due to a combination of loading cycles and the search for critical locations. The necessity of their automation and integration with traditional complexes is obvious and is confirmed by the availability of commercial software products, as well as normative documents [1-3].

\section{Literature reviews and problem statement}

The presence of fatigue cracks on the surface of structural elements (MUPs) aggravates the problem of the calculated values of strength characteristics under the influence of corrosive media, which has not found its full solution to date [4]. In this connection, it is necessary to correct a number of shortcomings related to the lack of relevance of the relevant normative and technical documents (NTDs).

In [5] the methodology of improving the regulatory provision of operational safety of pipeline systems with vibration accounting is given. Mathematical model and algorithm for predicting the life of pipeline systems is proposed. The mathematical model makes it possible to develop normative recommendations on the assessment of the vibrational state of pipelines [5]. The effect of operational factors on the corrosion-fatigue failure of the steels of the main oil and gas pipelines is fully reflected in $[1,3]$. These methods are advisable to use for the problem of improving regulatory documents related to the corrosion protection and strength of MUPs [1-3, 5].

The object of research is metal underground pipelines in conditions of corrosion-fatigue failure.

The subject of research is normative documents, which should be specified and improved on the basis of information obtained from the monitoring of the MUPs operation.

\section{The aim and objectives of research}

The aim of research is selection of information on the improvement of regulatory and technical support for monitoring the quality of metal underground pipelines in conditions of fatigue and the influence of aggressive corrosive environment, which will improve the quality of their non-destructive testing.

To achieve this aim, it is necessary to build a conceptual model of processes and develop recommendations on its rational functioning, taking into account the accumulation of defects and their distribution in the pipeline metal.

\section{Research results on information support of quality control of underground pipelines}

Normative documents [1-3] for technical diagnostics of underground metal pipelines in a corrosive (soil) environment must take into account the following elements (stages) [5], the interpretation of which is advisable to be improved taking into account more modern regulatory and methodological support:

- quantitative criteria for assessing the reliability of the investment project (improving the technology of corrosion protection of metal UPs);

- normative documents on corrosion and strength of structural elements;

- the calculated or experimental determination of the zones of location of the largest cyclic voltage and their corresponding values, depending on the number of cycles according to [1];

- in cases of corrosion-fatigue damage, calculation for fatigue should be carried out taking into account the requirements regarding the choice of permissible parameters for cyclic stresses and the actual number of cycles, accumulation of damage $[4,6,7]$;

- checking the actual thickness of the walls of the stretched and neutral zones. 
In the case of a decrease in strength characteristics of the metal below the requirements of NDs, but maintaining satisfactory characteristics of ductility and toughness, continued operation with design parameters is allowed with satisfactory results of the verification test for strength from internal pressure (safety margin relative to the actual yield strength of at least 1.5) and compliance with requirements of NDs [1]. It should be noted that existing normative documents are based on methods for assessing the maximum permissible strength characteristics of a metal, not including a sufficient amount of data to diagnose changes in the operation process.

Criteria characterizing the technical condition and residual life of the pipeline are the following parameters: pressure, temperature, working medium, mechanical load, vibration loads, fatigue strength, wear during operation [5].

When compiling the lists of pipeline systems, the defining characteristic is the functional affiliation of the pipeline [5]. For this, the pipelines are systematized and the criteria for their strength and reliability are established, taking into account the belonging of the software to a certain type [5]. An example can be trunk gas pipelines and oil pipelines, underground steel pipelines of cold and hot water supply system, etc.

Let's confine ourselves to the consideration of underground gas pipelines located in the soil electrolyte under conditions of low cycle fatigue. For MUPs, high-frequency fatigue is not observed [6]. To improve the NDs [1-3], it is advisable to build a complex mathematical model that will combine the physicochemical model of fatigue-corrosion processes of the type [7], the method of damage accumulation [8] and elements of the risk theory [9].

To estimate the rate of growth of the fatigue crack in the metal at the mean rectilinear section of the kinetic curve, let's use the Paris equation [10]:

$$
\mathrm{V}_{\mathrm{a}}=\mathrm{da} / \mathrm{dN}=\mathrm{C}_{\mathrm{t}}(\Delta \mathrm{K})^{\mathrm{n}}, \quad \Delta \mathrm{K}_{\mathrm{th}}<\Delta \mathrm{K}<\mathrm{K}_{\mathrm{IC}},
$$

where $2 \mathrm{a}=\mathrm{L}_{\mathrm{T}}$ - crack length, $\mathrm{N}$ - the number of load cycles, $\mathrm{K}$ - stress intensity factor (SIF) (used in linear fracture mechanics to describe stress fields near the crack tip), $\Delta \mathrm{K}-\mathrm{SIF}$ range, $\mathrm{C}_{\mathrm{t}}$ and $\mathrm{n}$ - the so-called Paris constants, $\Delta \mathrm{K}_{\mathrm{th}}$ - fatigue threshold, $\mathrm{K}_{\mathrm{IC}}$ - fracture toughness of the material.

The relation (1) is improved $[11,12]$ :

$$
\text { da } / d N=F\left(C_{i}, P_{j}(\sigma), A_{n}(\tau), B_{m}(S)\right),
$$

where $\mathrm{F}$ - the symbol of the functional dependence, $\mathrm{C}_{\mathrm{i}}$ - the constants characterizing the materialenvironment system, $\mathrm{P}_{\mathrm{j}}(\sigma)$ - the parameters characterizing the stress-strain state of the material and are functions of the external forces applied to the body, $A_{n}(\tau)$ - the parameters that determine physicochemical processes occurring between the deformed metal and the corrosive medium in time $\tau, \mathrm{B}_{\mathrm{m}}(\mathrm{S})$ - parameters characterizing the state of the surfaces of the material $\mathrm{S}$, which are formed upon destruction.

The rate of growth of the corrosion crack is characterized by three main parameters $\mathrm{K}_{\max }$, $\mathrm{pH}_{\mathrm{tC}}, \mathrm{E}_{\mathrm{tC}}$ and the corresponding equation takes the form [12, 13]:

$$
\mathrm{V}_{\mathrm{ae}}=(\mathrm{da} / \mathrm{dN})_{\mathrm{e}}=\mathrm{F}\left(\mathrm{C}_{\mathrm{i}}, \mathrm{K}_{\max }, \mathrm{pH}_{\mathrm{tC}}, \mathrm{E}_{\mathrm{tC}}\right),
$$

where $\mathrm{K}_{\max }$ - the maximum SIF value in the cycle for normal breakaway cracks, $\mathrm{pH}_{\mathrm{tC}}$ - the hydrogen index of the medium, $\mathrm{E}_{\mathrm{tC}}$ - the electrode potential of the metal.

Let's generalize the Paris equations for determining the crack propagation velocity $\mathrm{V}_{\mathrm{a}}$, taking into account the information of $[10-12,14]$ :

$$
\mathrm{V}_{\text {aep }}=\mathrm{da} / \mathrm{dN}=\mathrm{C}_{\mathrm{a}} \times\left(\Delta \mathrm{K}(\mathrm{a}, \Delta \mathrm{a}, \Delta \sigma), \mathrm{K}_{\text {max }}, \mathrm{pH}_{\mathrm{tC}}, \mathrm{E}_{\mathrm{tC}}\right)^{\mathrm{n}}, \Delta \mathrm{K}_{\mathrm{th}}<\Delta \mathrm{K}<\mathrm{K}_{\mathrm{IC}},
$$

where $\Delta \mathrm{a}$ - the fracture quantum, $\Delta \sigma$ - stress range, $\mathrm{n}, \mathrm{C}_{\mathrm{a}}$ - the constants characterizing the "material (steel) - medium" system. 
The durability (resource) of a structural element with a crack, that is, the period $\mathrm{N}_{\mathrm{p}}$ is calculated by a formula similar to $[11,14]$ :

$$
\mathrm{N}_{\mathrm{P}}=\mathrm{C}_{\mathrm{a}} \int_{\mathrm{ai}}^{\mathrm{ac}} \frac{\mathrm{da}}{\left(\Delta \mathrm{K}(\mathrm{a}, \Delta \mathrm{a}, \Delta \sigma), \mathrm{K}_{\max }, \mathrm{pH}_{\mathrm{tC}}, \mathrm{E}_{\mathrm{tC}}\right)^{\mathrm{n}}}, \quad \mathrm{k}_{\mathrm{N}}=\mathrm{N}_{\mathrm{P}} / \mathrm{N}_{\mathrm{P} *},
$$

where ai - the initial size of the macrocrack in the material, ac - the critical size of the fatigue macrocrack, $\mathrm{N}_{\mathrm{P} *}$ - the number of load cycles of the base sample, and $\mathrm{k}_{\mathrm{N}}$ - the relative number of load cycles. The parameter $\mathrm{ai}=\mathrm{d}_{*}$, where $\mathrm{d}_{*}$ is the size of the pre-destruction zone $[13,14]$.

$\mathrm{pH}_{\mathrm{tC}}, \mathrm{E}_{\mathrm{tC}}$ parameters can be used for local anodic dissolution (LAD) and hydrogen cracking (HC) mechanism [12].

The method of quantitative estimation of LAD and the mechanism of $\mathrm{HC}$ is based on the assumption $[12,13]$ :

$$
\Delta(\mathrm{da} / \mathrm{dN})_{\mathrm{e}}=(\mathrm{da} / \mathrm{dN})_{\mathrm{e}}-(\mathrm{da} / \mathrm{dN})_{\mathrm{a}}=\Delta(\mathrm{da} / \mathrm{dN})_{\mathrm{eA}}+\Delta(\mathrm{da} / \mathrm{dN})_{\mathrm{eH}}
$$

where $(\mathrm{da} / \mathrm{dN})_{\mathrm{e}}$ and $(\mathrm{da} / \mathrm{dN})_{\mathrm{a}}$ - the components of the propagation velocity of the crack, $\Delta(\mathrm{da} / \mathrm{dN})_{\mathrm{e}}, \Delta(\mathrm{da} / \mathrm{dN})_{\mathrm{eA}}$ and $\Delta(\mathrm{da} / \mathrm{dN})_{\mathrm{eH}}$ - the change in the components of the propagation velocity of the crack caused by LAD and HC.

The expression in the first approximation, based on the Faraday law, can be obtained as follows $[12,15]$ :

$$
\Delta(\mathrm{da} / \mathrm{dN})_{\mathrm{eA}}=\beta_{\mathrm{A}} \times \Delta \mathrm{E}_{\mathrm{A}}, \Delta(\mathrm{da} / \mathrm{dN})_{\mathrm{eH}}=\beta_{\mathrm{H}} \times \Delta \mathrm{E}_{\mathrm{H}},
$$

where $\beta_{\mathrm{A}}$ - the coefficient characterizing the "material (steel)-medium" system under investigation and depends on the density and atomic mass of the metal, the charge of cations that penetrate into solutions, the Faraday constant, the conductivity of electrolytes, the shape of the crack and the stress-strain state in the vicinity of the crack, $\Delta \mathrm{E}_{\mathrm{A}}$ - takes into account the synergetic effects (influence of voltage, hydrogen electrolytes present) on LAD, $\beta_{\mathrm{H}}$ - the coefficient characterizing the "material (steel) - medium" system and depends on the exposure time of the medium, the quantities of hydrogen and the fullness of the crack, the diffusion rate, the critical concentration of hydrogen in the stress section with the maximum tension, the stress-strain state in the vicinity of the crack, and other parameters that can' yet be determined accurately, $\Delta \mathrm{E}_{\mathrm{H}}$ - takes into account synergistic effects (stress effect, processes LAD, etc.) and provides these changes in hydrogen depolarization in the fracture as a result of corrosion fatigue.

The energy criterion for fracture mechanics is also based on the energy criterion of fracture mechanics, according to which an act of destruction occurs in an arbitrary elementary volume of material if the total irreversibly dispersed energy of plastic deformation $\mathrm{W}$ of all load cycles reaches a critical value $\mathrm{W}_{\mathrm{Z}}$ equal to the material destruction energy $[16,17]$ :

$$
\mathrm{W}=\alpha \times \mathrm{W}_{\mathrm{Z}} \Rightarrow \mathrm{W}_{\mathrm{Z}}=\mathrm{W}_{0}+\mathrm{W}_{\mathrm{S}}+\Delta \mathrm{N} \times \mathrm{W}_{\mathrm{C}}=\alpha \times \gamma_{\mathrm{T}} \times \Delta \mathrm{a}=\alpha \times \sigma_{0 \mathrm{f}} \times \delta_{\mathrm{fC}} \times \Delta \mathrm{a},
$$

where $\mathrm{W}_{\mathrm{Z}}$ - the material destruction energy for a single static load, $\alpha$ - the Morrow coefficient [16], $\mathrm{W}_{0}=\gamma_{\mathrm{T} 0} \times \Delta \mathrm{a}, \mathrm{W}_{0}$ and $\gamma_{\mathrm{T} 0}$ - the energy and specific dissipation energy of plastic deformations under the previous load, respectively, $\sigma_{0 \mathrm{f}} \approx\left(\sigma_{\mathrm{T}}+\sigma_{\mathrm{B}}\right) / 2, \sigma_{\mathrm{T}}, \sigma-$ the yield strength and strength of the material, respectively, $\delta_{\mathrm{fC}}$ - critical crack opening, $\gamma_{\mathrm{T}}=\sigma_{0 \mathrm{f}} \times \delta$ - specific fracture energy needed to form a unit of crack length.

For the component $\mathrm{W}_{\mathrm{S}}$ related to the averaged stresses $\mathrm{W}_{0}=\gamma_{\mathrm{T} 0} \times \Delta \mathrm{a}, \mathrm{W}_{0}$ and the cyclic strain energy WC, the following expressions are given [17, 18]:

$$
\mathrm{W}_{\mathrm{S}}=\sigma_{0 \mathrm{f}} \times \delta_{\max } \times \Delta \mathrm{a}, \quad \mathrm{W}_{\mathrm{C}}=\int_{0}^{1_{\mathrm{pf}}} \sigma_{0 \mathrm{f}}\left[\delta_{\mathrm{f} \max }(\mathrm{s})-\delta_{0}\right] \mathrm{ds},
$$


where $\delta_{\max }$ - the maximum crack opening, $\delta_{\text {fmax }}\left(s_{t}\right)=(1-R) \times \delta_{\max }\left(s_{t}\right) / 2-$ the opening of the sides of the additional cut $\left(0 \leq \mathrm{s}_{\mathrm{t}} \leq \mathrm{l}_{\mathrm{pf}}\right)$, which is implied with the opening under static load, $1_{\mathrm{pf}}-$ length of the plastic zone, $\mathrm{R}=\mathrm{P}_{\min } / \mathrm{P}_{\max }$ - load cycle asymmetry coefficient, $\mathrm{P}_{\min }, \mathrm{P}_{\max }-$ minimum and maximum loads in the sample with a crack.

The values of $\mathrm{W}, \mathrm{W}_{\mathrm{Z}}(8)$ are determined through the parameters of the stress-strained state (SSS) in the zone of the fracture advance as the area of the corresponding sections under the model tension diagram for the reinforcement material, approximated by the power law for the voltage $\sigma[16,18]$ :

$$
\sigma=\sigma_{\mathrm{T}}+\zeta \times \varepsilon^{\mathrm{m}}
$$

where $\zeta$ - coefficient of strain hardening of the material, $\sigma_{\mathrm{T}}, \zeta, \mathrm{m}-$ experimentally established constants for this material.

The critical expansion of the crack tip, taking into account the strengthening $\zeta$, is calculated by the formula [19]:

$$
\delta_{\mathrm{fC}}=\mathrm{C}_{0} \frac{\mathrm{K}^{2}}{\sigma_{0 \mathrm{f}} \mathrm{E}} ; \mathrm{C}_{0}=0,6\left(1-v^{2}\right)\left(\frac{2(1+v)(1+\zeta) \sigma_{0}}{3 \sqrt{\zeta} \mathrm{E}}\right)^{\zeta},
$$

where $v$ - Poisson ratio, E - Young's modulus.

The critical opening $\delta_{\mathrm{fC}}$ of the crack tip enters into the $\mathrm{CCO}$ criterion of strength (critical crack opening), which determines the ultimate equilibrium state of an elastic body with a crack at the time of reaching the opening crack $\delta_{\mathrm{fC}}[20]$ :

$$
\delta_{1}\left(\mathrm{~L}_{\mathrm{t}}, \sigma_{\mathrm{T}}\right)=\delta_{\mathrm{fC}} .
$$

With crack opening $\delta_{\mathrm{fC}}$ in a simplified version connected SIF K and overpotential $\eta$ of metal dissolution reaction on the basis of the known relationships [20, 21]:

$$
\begin{gathered}
K=\sqrt{\frac{E}{1-v^{2}} \cdot\left(W P L-Z_{\mathrm{si}} F \rho \delta \frac{\eta}{M}\right)}, \\
K=K_{1 S C C}=\sqrt{E \cdot \sigma_{\mathrm{T}} \cdot \delta_{\mathrm{fC}}},
\end{gathered}
$$

where $Z_{\mathrm{si}}$ - the formal charge of the solvated (hydrated) ions, $\mathrm{F}=96500 \mathrm{Kl} / \mathrm{mol}$ - the Faraday constant, $\delta=2 \mathrm{r}$ - the width of the front of the impending microcrack, $\mathrm{m}, \mathrm{M}$ is the molecular weight of the metal, $\mathrm{Kg} / \mathrm{mol}\left(\mathrm{M}=0,0558 \mathrm{~kg} / \mathrm{mol}\right.$ - for steel), $\mathrm{K}_{1 \mathrm{SCC}}$ - the threshold value of the SIF, that is, the minimum value of the corresponding to the beginning of the crack propagation under the influence of the mechanical load and the corrosive medium, WPL - the surface energy of plastic deformation, $\eta$ - electrochemical overpotential (B), that is, the deviation of the electrode potential from its equilibrium (with respect to the electrode composition of the solution) thermodynamic value when the electrode under the current is polarized. It should be noted that the second relation (12) for $\mathrm{K}_{1 \mathrm{SCC}}$ follows from the $\mathrm{CCO}$ of the strength criterion (critical crack opening) (11).

The WPL parameter is included in the known formula (strength criterion) of GriffithsIrvine-Orowan [20, 22]:

$$
\sigma_{*}=\sqrt{\frac{4 \mathrm{E} \cdot \mathrm{WPL}}{\pi \cdot \mathrm{L}_{\mathrm{T}}\left(1-v^{2}\right)}}, \quad \sigma_{*}=\sqrt{\frac{4 \mathrm{E} \cdot \mathrm{WPL}}{\pi \cdot \mathrm{L}_{\mathrm{T}}}},
$$

where the first formula is written for plane deformation, the second for a plane stress state, $\sigma_{*}-$ the critical stress, WPL $=\mathrm{J} / 2, \mathrm{~J}-$ the Rice's integral [23]. 
According to the results of contact deformation of various steel (17ГС, 17ГС-У, 06Г2НАБ, 10Г2ФБ, 10Г2ФБ-У, 10ЧГНМАЮ) used in MUPs [6], an empirical relationship is established that links SIF K to WPL [21]:

$$
\mathrm{K}=\mathrm{a}_{1} \cdot \sqrt{\mathrm{WPL}}-\mathrm{a}_{2} ; \mathrm{a}_{1}=226 \cdot 10^{6} \frac{\sqrt{\mathrm{H}}}{\mathrm{M}} ; \mathrm{a}_{2}=6,98 \mathrm{MPa} \sqrt{\mathrm{m}}
$$

In the ratio (15), it is necessary to set $\mathrm{a}_{1}=226, \mathrm{a}_{2}=6,98$, then the dimension of $\mathrm{K}$ will be given in MPA $\mathrm{MPa} \cdot \sqrt{\mathrm{m}}$, and WPL will be obtained in $\left(\mathrm{MJ}^{2}\right) / \mathrm{m}^{2}$.

To determine the density of the anode current $\mathrm{I}_{\mathrm{A}}$ at the crack tip, taking into account the energy characteristics of the surface WPL layer, let's use the generalized Kaeshe-type relationship [15, 21]:

$$
\mathrm{I}_{\mathrm{A}}=\frac{\alpha \cdot \chi \cdot \Delta \psi_{\mathrm{ak}}}{\delta \cdot \ln ((\mathrm{h}+\mathrm{c}+\mathrm{r}) / \delta)} \cdot\left(1+\beta_{\mathrm{w}} \cdot\left(\frac{\mathrm{WPL}-\mathrm{WPL} 0}{\mathrm{WPL} 0}\right)^{\mathrm{S}}\right)
$$

where $\alpha$ - the angle at the crack tip, $\chi$-the electroconductivity of the electrolyte, $\Delta \psi_{\text {ak }}$ - the ohmic change in the electric potential between the anodic and cathodic parts, $\mathrm{h}, \mathrm{c}$ - the depth of the cavity and the crack, respectively, $\mathrm{r}$ - the radius of the projection curvature of the juvenile surface. The relation (16) is written for the crack tip, which is the anode, $\beta_{\mathrm{w}}, \mathrm{S}$, WPL0 are experimentally determined constants.

The empirical initial formula for calculating the boundary of corrosion fatigue of metals has the form [7]:

$$
\sigma_{\mathrm{ve}}=\sigma_{\mathrm{vp}}\left[1,128-2,849 \lg \left(\mathrm{Q}_{\mathrm{dr}} / \mathrm{Q}_{\mathrm{cor}}\right)\right]
$$

where $\sigma_{\mathrm{vp}}, \sigma_{\mathrm{ve}}$ - fatigue limit (mechanical stress) in air and in the environment, respectively, $\mathrm{Q}_{\mathrm{dr}}, \mathrm{Q}_{\mathrm{cor}}$ - the amount of electricity going for additional dissolution of the deformed metal at $\sigma_{\mathrm{vp}}$ and its corrosion in the absence of deformation. For stainless steels used in pipelines, the uncertainty of estimating $\sigma_{\mathrm{vp}}, \sigma_{\mathrm{ve}}$ does not exceed $8 \%$.

For the basic model of accumulation of damages for metals under conditions of automotive deformation (fatigue), the Manson-Halford model based on the damage curve [24, 25] was adopted:

$$
\mathrm{D}_{\mathrm{s}}=\left(\mathrm{N}_{\mathrm{s}} / \mathrm{N}_{\mathrm{fs}}\right)^{\mathrm{q}}, \quad \mathrm{q}=\left(\mathrm{N}_{\mathrm{f}(\mathrm{s}-1)} / \mathrm{N}_{\text {fis }}\right)^{\beta}, \quad \beta=\mathrm{m}+\mathrm{a} \cdot \operatorname{sign}\left(\mathrm{N}_{\mathrm{f} 2} / \mathrm{N}_{\mathrm{f} 1}-1\right),
$$

where $\mathrm{D}_{\mathrm{s}}$ - the material damageability at the s-th degree (area) of deformation ( $\mathrm{s}=1,2,3, \ldots, \mathrm{ns}$ ), $\mathrm{N}_{\mathrm{s}}$ - the number of deformation cycles on the s-th power, $\mathrm{N}_{\mathrm{fs}}-$ the number of cycles before the sample is destroyed under the deformation mode, which corresponds to the s-th power, $\mathrm{q}, \beta, \mathrm{m}, \mathrm{a}$ - empirical constants, for a number of materials (metals) $\beta \approx 0.4$.

The fatigue damage model is simply described by the ratio of the damage denoted as $\mathrm{D}_{\mathrm{m}}$ to the number of cycles $\mathrm{N}$.

Let's confine ourselves to a consideration of the low-cycle fatigue of metals. The evolution equation for describing the process of low-cycle fatigue of metals is [26, 27]:

$$
\begin{gathered}
D_{\mathrm{z}}=\sum \Delta \mathrm{D}_{\mathrm{s}}=\sum_{\mathrm{s}=1}^{\mathrm{ns}} \Delta \mathrm{D}_{\mathrm{s}}, \\
\Delta \mathrm{D}_{\mathrm{s}}=\mathrm{f}_{\mathrm{s}}\left(\beta_{\mathrm{u}}\right)\left(\mathrm{z}_{\mathrm{s}}\right)^{\alpha_{\mathrm{s}}}\left(1-\mathrm{D}_{\mathrm{s}}\right)^{-\mathrm{r}_{\mathrm{s}}} \Delta \mathrm{z}_{\mathrm{s}}\left(\alpha_{\mathrm{s}}+1\right) /\left(\mathrm{r}_{\mathrm{s}}+1\right), \quad \mathrm{D}_{\mathrm{z}} \Rightarrow \mathrm{D}_{\mathrm{f}}, \\
\beta_{\mathrm{u}}=\sigma / \sigma_{\mathrm{u}} ; \quad \sigma=\sigma_{\mathrm{kk}} / 3 ; \quad \mathrm{f}_{\mathrm{s}}\left(\beta_{\mathrm{u}}\right)=\exp \left(-\mathrm{k}_{\mathrm{s}} \beta_{\mathrm{u}}\right),
\end{gathered}
$$


where $\mathrm{z}_{\mathrm{s}}=\left(\mathrm{W}_{\mathrm{s}}-\mathrm{W}_{\mathrm{a}}\right) /\left(\mathrm{W}_{\mathrm{fp}}-\mathrm{W}_{\mathrm{a}}\right) ; \Delta \mathrm{z}_{\mathrm{s}}=\Delta \mathrm{W}_{\mathrm{s}} /\left(\mathrm{W}_{\mathrm{fp}}-\mathrm{W}_{\mathrm{a}}\right) ; \Delta \mathrm{W}_{\mathrm{s}}=\rho_{\mathrm{ij}} \Delta \mathrm{e}_{\mathrm{sij}}, \mathrm{D}_{\mathrm{z}}, \mathrm{D}_{\mathrm{f}}-$ the integral volume damageability of the material and its critical value, $\mathrm{W}_{\mathrm{a}}$ - the specific energy value $\mathrm{W}_{\mathrm{s}}$ at the end of the first stage of the process of fatigue damage accumulation at low cycle fatigue (LCF), $\mathrm{W}_{\mathrm{fp}}$ - the local value of the specific fatigue damage accumulation energy corresponding to the creation of the macroscopic crack for LCF, $\rho_{\mathrm{ij}}, \mathrm{e}_{\mathrm{ij}}-$ the components of the residual microstress tensors and the deviator of elastic deformations, respectively, $\sigma_{\mathrm{ii}}, \sigma-$ the principal components and the first invariant of the macroscopic stress tensor, $\alpha_{s}, r_{s}, k_{s}-$ parameters (physical characteristics) of the material (determined experimentally).

The law of damage can be summarized as follows (including the period of energy accumulation) [28]:

$$
\frac{\mathrm{dD}_{\mathrm{z}}}{\mathrm{dt}}=\left(\frac{\mathrm{Ee}^{2}}{2 \mathrm{Z}_{\mathrm{S}}}\right)^{\lambda} \mathrm{e}^{\lambda}\left(\frac{\mathrm{de}}{\mathrm{dt}}\right)
$$

where $\mathrm{e}=\mathrm{e}_{\mathrm{k}} / 3$ - the first invariant of the strain tensor, (20) introduces 2 damage parameters: the impact force $Z_{\mathrm{S}}$ and the damage index $\lambda$.

As a criterion for completing the stage of development of scattered microdamages and creating a microcrack, the criterion for achieving a critical value $\mathrm{D}_{\mathrm{f}}(19)$ can be adopted.

Relation (1)-(20) is useful for describing the LCF of the material both in zones with developed non-stationary plastic deformations and in elastic zones of the material (metal) under cyclic loading.

Let's add the system (1)-(20) with information on the parameters characterizing a particular underground pipeline under operating conditions. For this, it is necessary to take into account the influence on the reliability $\mathrm{Y}_{\mathrm{N}}$ of MUP of the internal working pressure $\mathrm{p}_{\mathrm{S}}$, the stresses $\sigma_{\mathrm{y}}$ from the temperature differences $\Delta \mathrm{T}$, the unevenness of laying the pipeline in the trench, in particular [29]:

$$
\rho_{\mathrm{K}}=\frac{8(\mathrm{H}+\Delta \mathrm{H})}{\mathrm{L}_{\mathrm{x}}^{2}+4(\mathrm{H}+\Delta \mathrm{H})^{2}} ; \quad \mathrm{Y}_{\mathrm{N}}=\mathrm{Y}\left(\sigma_{\mathrm{y}}, \mathrm{p}_{\mathrm{S}}, \Delta \mathrm{T}, \rho_{\mathrm{K}}\right) ; \quad \beta_{\mathrm{Y}}=\frac{\mathrm{Y}_{\mathrm{N}}}{\mathrm{Y}_{\mathrm{S}}},
$$

where, $\rho_{K}$ - the pipe curvature in the pipeline section, $\mathrm{H}$ - the design change in the pipeline location mark, $\Delta \mathrm{H}$ - the depth error of the pipeline laying (depth), $\mathrm{L}_{\mathrm{x}}$ - the pipeline length with the same curvature $\rho_{\mathrm{K}}, \mathrm{Y}_{\mathrm{N}}$ - the reliability function of the pipeline section (mathematical expectation of the safety reserve ), $Y_{S}$ - standard (normative) value of the reserve strength, $\beta_{\mathrm{Y}}$ - safety characteristic.

For a pipe weakened on the outer surface by a cavern-like defect of depth $h$ with a crack at the tip of depth $\mathrm{c}$, we can write the ratio for the stress concentration coefficient $\mathrm{K}_{\mathrm{t}}$ and the internal critical pressure $\mathrm{p}=\mathrm{p}_{\mathrm{S}}$, similar to those presented in [21]:

$$
\begin{gathered}
\mathrm{K}_{\mathrm{t}}=\left(2,021-1,301 \cdot \beta_{\mathrm{K}}+0,727 \cdot \beta_{\mathrm{K}}^{2}-0,147 \cdot \beta_{\mathrm{K}}^{3}\right) \cdot \frac{\mathrm{d}}{\mathrm{d}_{1}-\mathrm{c}} ; \\
\mathrm{p}_{\mathrm{S}}=\frac{2 \sqrt{2} \cdot \mathrm{d} \cdot \sigma_{\mathrm{T}}}{3 \mathrm{~K}_{\mathrm{t}} \cdot \mathrm{D}} \cdot \frac{\left(1,5+\mathrm{K}_{\mathrm{z}}\right) \cdot\left(\mathrm{r}_{0}+\mathrm{c}\right)^{4}}{\left(\mathrm{r}_{0}+\mathrm{c}\right)^{4}+0,5 \cdot \mathrm{r}_{0}^{2}\left(\mathrm{r}_{0}+\mathrm{c}\right)^{2}+\mathrm{r}_{0}^{4}},
\end{gathered}
$$

where

$$
\mathrm{K}_{\mathrm{z}}=\left(\frac{\mathrm{d}_{1}-\mathrm{c}}{2} \cdot \frac{2\left(\mathrm{~d}_{1}-\mathrm{c}\right)+3 \mathrm{r}_{0}}{\mathrm{~d}_{1}-\mathrm{c}+\mathrm{r}_{0}}-\frac{3 \mathrm{~d}}{2 \mathrm{~K}_{\mathrm{t}}}\right) /\left(\frac{\mathrm{d}}{\mathrm{K}_{\mathrm{t}}}+\frac{\mathrm{r}_{0}}{3} \cdot\left(\frac{\mathrm{r}_{0}^{3}}{\left(\mathrm{~d}_{1}-\mathrm{c}+\mathrm{r}_{0}\right)^{3}}-1\right) ; \quad \beta_{\mathrm{K}}=\frac{\mathrm{r}_{0}}{\mathrm{~d}_{1}-\mathrm{c}}\right.
$$

$\mathrm{D}$ - diameter of the pipe, $\mathrm{d}$ - the thickness of the pipe wall, the critical pressure $\mathrm{p}_{\mathrm{S}}$ corresponds to the condition for reaching the limiting (plastic) state at the crack peak, according to the Huber-MisesHencky yield criterion [30]. 
This is a solution of scientific and applied problems of improving regulatory documents for operational safety and lifetime of the terminal of reactor nuclear power plants by developing a scientific and reasonable mathematical model and diagnostic algorithm [31]. Based on the research, normative acts were developed to assess the technical condition of the pipeline metal and to determine its resources for reassignment of operation and safe operation during the project period [31].

Three UPs modes are considered: NO - normal operation, VNO - violation of normal operating conditions, HT - hydraulic tests. Then the accumulated fatigue damage of equipment and pipelines from operating cycles of loading is determined by the coefficient $\mathrm{a}_{\mathrm{ex}}$ [31]:

$$
\mathrm{a}_{\mathrm{ex}}=\frac{\mathrm{N}_{\mathrm{NE}}}{\left[\mathrm{N}_{0}\right]_{\mathrm{NE}}}+\frac{\mathrm{N}_{\mathrm{VNO}}}{\left[\mathrm{N}_{0}\right]_{\mathrm{VNO}}}+\frac{\mathrm{N}_{\mathrm{HT}}}{\left[\mathrm{N}_{0}\right]_{\mathrm{HT}}},
$$

where $[\mathrm{N} 0]_{\mathrm{NO}},[\mathrm{NO}]_{\mathrm{VNO}},[\mathrm{NO}]_{\mathrm{HT}}-$ number of cycles of the pipeline in the load modes of $\mathrm{NO}$, VNO, HT accordingly, $\mathrm{N}_{\mathrm{NO}}, \mathrm{N}_{\mathrm{VNO}}, \mathrm{N}_{\mathrm{HT}}$ - the actual number of cycles in the load modes NO, VNO, HT.

To check the corrosion process taking into account the polarization potential (PP) $\mathrm{U}_{\mathrm{P}}$, a criterial relationship is used to determine the rate of residual corrosion of the metal in the defect of the insulation coating, in particular at the crack tip, which is the anode region [32]:

$$
\mathrm{I}_{\mathrm{A}}=\mathrm{I}_{\mathrm{AY}} \cdot 10^{\mathrm{V}_{\mathrm{pt}}} ; \quad \mathrm{V}_{\mathrm{pt}}=\frac{\overline{\mathrm{E}}_{\mathrm{c}}-\mathrm{U}_{\mathrm{P}}}{\mathrm{b}_{\mathrm{at}}},
$$

where $\overline{\mathrm{E}}_{\mathrm{c}}$ - the average corrosion potential, $\mathrm{I}_{\mathrm{AY}}$ - the density of the corrosion (anode) current (metal corrosion rate) at $\overline{\mathrm{E}}_{\mathrm{c}}=\overline{\mathrm{E}}_{\mathrm{p}}, \mathrm{b}_{\mathrm{at}}$ - Tafel slope of the anodic polarization curve.

To control the corrosion process in the type of stress concentrator, let's use the results of experimental studies [11] for steel 20 and the relation (24).

Let's consider the situation when the relative tensile stress $\sigma / \sigma_{T}$ varies from 0 to 1 [11]. At the same time $\overline{\mathrm{E}}_{\mathrm{c}}=-0.092 \mathrm{~V}$, while the corrosion current for steel 20 in a $3 \%$ solution of $\mathrm{NaCl}$ increases linearly from $0.1 \mathrm{~A} / \mathrm{m}^{2}$ to $0.4 \mathrm{~A} / \mathrm{m}^{2}$. Taking these experimental data into account, let's generalize (24) and, as a result, obtain:

$$
\mathrm{I}_{\mathrm{A}}=\mathrm{I}_{\mathrm{AY}}\left(1+\beta_{\mathrm{S}} \times \sigma / \sigma_{\mathrm{T}}\right) \cdot 10^{\mathrm{V}_{\mathrm{pt}}} ; \quad \beta_{\mathrm{S}}=3,
$$

where $\beta_{\mathrm{S}}$ - a dimensionless empirical parameter for steel 20 in a $3 \%$ solution of $\mathrm{NaCl}$.

The polarization potential (PP) $\mathrm{U}_{\mathrm{P}}$ is considered the main criterion for corrosion protection of metal structures in an electrically conductive medium $[32,33]$. It is empirically established and confirmed by many studies that the protective PP for steel underground pipelines should be in the range from -0.85 to $-1.15 \mathrm{~V}$ relative to the mid-sulfate reference electrode (RE) [33].

In real conditions, the relationship between the constant and alternating current components $i_{A}$ flowing between the metal and the medium can significantly differ through different characteristics of rectifiers and reactances. These shortcomings of known methods were eliminated using the proposed method for determining the PP with the ohmic component removed from the measurements of constant and variable electric voltages [33]. To get rid of the ohmic component from the measurement of the potential difference $\mathrm{U}_{\mathrm{MG}}$, the value of the alternating voltage was set in accordance with the constant using the harmonic coefficient determined from the measurements of the constant $\mathrm{U}_{\mathrm{GG}}$ and the variable voltage $\mathrm{V}_{\mathrm{GG}}$ at the same resistance between the reference electrode (RE) and the auxiliary electrode (AE). PP is determined by the formula [33]:

$$
\mathrm{U}_{\mathrm{P}}=\mathrm{U}_{\mathrm{MG}}-\mathrm{V}_{\mathrm{MG}} \times \mathrm{U}_{\mathrm{GG}} / \mathrm{V}_{\mathrm{GG}},
$$

where $\mathrm{U}_{\mathrm{MG}}$ - the potential difference between the pipeline metal and the electrode installed on the soil surface, $\mathrm{k}_{\mathrm{G}}=\mathrm{V}_{\mathrm{GG}} / \mathrm{U}_{\mathrm{GG}}$ - the measured harmonic coefficient. 
The destruction of the pipe is possible when the defect depth $\mathrm{h}+\mathrm{c}$ reaches the critical size $\mathrm{h}_{\mathrm{cr}}$, and the crack length $\mathrm{L}_{\mathrm{T}}$ will exceed the critical value $\mathrm{L}_{\mathrm{cr}}$.

To estimate $h_{c r}$, let's use the relation $[1,34]$ :

$$
\begin{gathered}
\mathrm{h}_{\mathrm{cr}}=\mathrm{h}+\mathrm{c}_{\mathrm{cr}}=\mathrm{d}-\mathrm{L}_{\mathrm{T}} \sqrt{0,1785 \frac{\mathrm{p}_{\mathrm{s}}}{\sigma_{\mathrm{B}}}}, \\
\mathrm{h}_{\mathrm{cr}}=\mathrm{d} \sqrt{\frac{\mathrm{L}_{\mathrm{T}}}{\mathrm{D}}\left(1-\frac{\mathrm{p}_{\mathrm{S}}(\mathrm{D}-2 \mathrm{~d})}{2 \mathrm{~K}_{\mathrm{K}} \mathrm{K}_{\mathrm{S}} \sigma_{\mathrm{B}} \mathrm{d}}\right),} \\
\mathrm{L}_{\mathrm{T}} \Rightarrow \mathrm{L}_{\mathrm{cr}}= \\
=\frac{1}{\pi}\left(\frac{8 \mathrm{~d}}{\mathrm{p}_{\mathrm{S}} \mathrm{D}}\right)^{2} \mathrm{~K}_{\mathrm{fC}}^{2}, \quad \mathrm{~K}_{\mathrm{S}}=1+\frac{\mathrm{h}+\mathrm{c}}{\mathrm{d}} \sqrt{\frac{\mathrm{L}_{\mathrm{T}}}{\mathrm{D}}},
\end{gathered}
$$

where, $\mathrm{K}_{\mathrm{K}}$ - the coefficient of crack sensitivity, $\mathrm{c}_{\mathrm{cr}}$ - the critical value of the crack depth, $\mathrm{K}_{\mathrm{S}}-$ the coefficient that takes into account the change in pipe thickness in the defective section of the pipeline, $\mathrm{K}_{\mathrm{C}}$ the crack resistance parameter, which is determined experimentally by known mechanical testing methods. To determine $\mathrm{K}_{\mathrm{K}}$, laboratory mechanical tests are also carried out, in which the ratio of the strength limits of the defective and solid samples is taken into account [34]. It should be noted that the first formula (27) for $\mathrm{h}_{\mathrm{cr}}$ is empirical.

The term of accident-free operation of the $\mathrm{T}_{\mathrm{S}}$ facility (MUP) can be estimated from the formula [34]:

$$
\mathrm{T}_{\mathrm{S}}=\left(\mathrm{h}_{\mathrm{cr}}-\mathrm{h}_{\max }\right) / \mathrm{I}_{\mathrm{A}}
$$

where $h_{\max }$ - the geometric size of the defect of the maximum permissible depth, the dimension of the anode current $\mathrm{I}_{\mathrm{A}}-1 \mathrm{~mm} /$ year.

Just as in [35] let's use the product $\mathrm{k}_{\mathrm{P}}=\mathrm{k}_{1} \times \mathrm{k}_{2} \times \mathrm{k}_{3}, \mathrm{k}_{1}$ - the coefficient of commercial gain, $\mathrm{k}, \mathrm{k}_{2}$ - the coefficient of MUP competitiveness, $\mathrm{k}_{3}-$ MUP reliability factor $\left(\mathrm{k}_{3}=\mathrm{Y}_{\mathrm{N}}\right)$.

Taking into account these indices $\left(\mathrm{k}_{\mathrm{P}}=\mathrm{k}_{1} \times \mathrm{k}_{2} \times \mathrm{k}_{3}\right)$, just as in [35] the qualitative criterion (quality criterion) of the generalized MUP level takes the multiplicative form:

$$
\mathrm{Z}_{1}=\prod_{\mathrm{i}=1}^{\mathrm{m}} \mathrm{k}_{\mathrm{i}}=\mathrm{k}_{1} \cdot \mathrm{k}_{2} \cdot \mathrm{k}_{3} \cdot \mathrm{k}_{4} \cdot \mathrm{k}_{5} \cdot \mathrm{k}_{6} \cdot \mathrm{k}_{7} \cdot \mathrm{k}_{8} \Rightarrow \max
$$

where $\mathrm{k}_{4},\left(\mathrm{D}_{\mathrm{f}}\right), \mathrm{k}_{5}\left(\mathrm{p}_{\mathrm{S}}\right), \mathrm{k}_{6}\left(\sigma_{\mathrm{ve}}\right), \mathrm{k}_{7}\left(\mathrm{Y}_{\mathrm{N}}\right), \mathrm{k}_{8}\left(\mathrm{~T}_{\mathrm{S}}\right)$ - coefficients characterizing defectiveness $\mathrm{D}_{\mathrm{f}}$, strength $\mathrm{p}_{\mathrm{S}}$, corrosion fatigue limit $\sigma_{\mathrm{ve}}\left(\mathrm{N}_{\mathrm{P}}\right)$, reliability $\mathrm{Y}_{\mathrm{N}}$, term of accident-free operation $\mathrm{T}_{\mathrm{S}}(\mathrm{re}-$ source) of the structure.

Let's introduce the quality criterion $\mathrm{Z}_{2}$ in the additive form:

$$
\mathrm{Z}_{2}=\mathrm{a}_{1} \cdot \mathrm{k}_{1}+\mathrm{a}_{2} \cdot \mathrm{k}_{2}+\mathrm{a}_{3} \cdot \mathrm{k}_{3}+\mathrm{a}_{4} \cdot \mathrm{k}_{4}+\mathrm{a}_{5} \cdot \mathrm{k}_{5}+\mathrm{a}_{6} \cdot \mathrm{k}_{6}+\mathrm{a}_{7} \cdot \mathrm{k}_{7}+\mathrm{a}_{8} \cdot \mathrm{k}_{8} \Rightarrow \max
$$

where $a_{j}(j=1,2, \ldots, 8)-$ the weight coefficients.

Taking into account the information in [36-40], let's formulate the basic quantitative criteria for assessing the reliability of the investment project (improving the technology of corrosion protection of metal PTs) as in $[39,40]$, taking into account: DROI - the discounted rate of return on investment in the project, DPP - the payback period of the project, taking into account the discounting, the sensitivity of the project SR - safety margin of the project by its key parameters:

$$
\mathrm{N}_{\mathrm{DROI}}=\mathrm{NVP} / \mathrm{DCF}_{\mathrm{INV}}=\mathrm{PI}-1 ; \mathrm{N}_{\mathrm{DPP}}=1-\mathrm{DPP} / \mathrm{T}_{\mathrm{p}}
$$


where $\mathrm{DCF}_{\mathrm{INV}}$ - the discounted cash flow from investment activity, NPV - the net present value of the project, PI - the project profitability index, $\mathrm{T}_{\mathrm{P}}$ - the performance indicator horizon, $\mathrm{N}_{\text {DROI }}, \mathrm{N}_{\text {DPP }}$ - the reliability indicators of the project according to the DROI and DPP criteria.

The overall index of reliability of investment project $\mathrm{N}_{\mathrm{Z}}$, taking into account the risk, is determined in the same way as in $[36,38]$ by the criterion:

$$
\mathrm{N}_{\mathrm{Z}}=\mathrm{N}_{\text {DROI }} \times \mathrm{N}_{\text {DPP }} \times \mathrm{SR}(\mathrm{R})
$$

where SR - integral evaluation of project sensitivity using the key parameters of (1)-(28) and the risk R.

In areas with unsteady plastic deformation is expedient to use the criteria for adhesive strength biocorrosive aggressiveness of soil, mechanical criterion for the stress intensity factor (accounts for overstress of corrosion process), the criterion of defect corrosion resistance, criterion correlation to estimate the residual metal corrosion rate in the defect of the insulating coating together with introduced diagnostic weight characteristics and diagnostic value surveys that complement refines and improves the system of corrosion pipeline monitoring and can be used to control and optimize the corrosion process, and the development of corrosion protection guidelines $[39,40]$. Optimization of the conditions for the protection of structural elements of oil and gas industry, that are described and regulated by the state standard [2], can be conducted with their help.

The joint use of relations (1)-(32) and criteria for corrosion monitoring of pipelines [39] allows to study, in detail, from the standpoint of corrosion fatigue, electrochemistry, physics of surface processes, fracture mechanics and risk theory, the mechanisms of propagation of corrosion fatigue cracks in underground metal pipelines located in aggressive environments, in particular, in sea water and soil electrolyte.

An estimation of uncertainty regarding the term of accident-free operation of the pipeline $\delta \mathrm{T}_{\mathrm{S}}$ (MUP) (i. e. pipeline resource) according to formula (28) and data on pipe parameters, corrosion cracks and other [21]:

$$
\mathrm{T}_{\mathrm{S} 1}=12,9 \text { years, } \mathrm{T}_{\mathrm{S} 2}=18,7 \text { years, } \delta \mathrm{T}_{\mathrm{S}}=2\left(\mathrm{~T}_{\mathrm{S} 2}-\mathrm{T}_{\mathrm{S} 1}\right) /\left(\mathrm{T}_{\mathrm{S} 2}+\mathrm{T}_{\mathrm{S} 1}\right) \approx 0,37
$$

Taking into account information on the uncertainties of the density of the corrosion current $\mathrm{I}_{\mathrm{A}}(16)$, additional information about $\mathrm{I}_{\mathrm{A}}(25)$ and a number of parameters of the type $\mathrm{p}_{\mathrm{S}}, \mathrm{c}_{\mathrm{cr}}$, $\mathrm{h}_{\mathrm{cr}}$ are decreased the uncertainty $\delta \mathrm{T}_{\mathrm{s}}$ in the ratios (1)-(27) from $37 \%$ (33) to $9 \%$.

Based on the obtained results, it is possible to improve the normative and technical documents $[1,2]$ for metal pipelines in conditions of low-cycle corrosion fatigue.

\section{Conclusions}

1. A new complex mathematical model is proposed for estimating the resource and improving the quality of corrosion protection of metallic underground pipelines from the standpoint of corrosion fatigue, electrochemistry, surface physics, fracture mechanics and risk theory. The simulation takes into account the accumulation of damage in metals and allows to study the mechanisms of the propagation of corrosion fatigue cracks in underground metal pipelines located in corrosive environments, in particular, in sea water and soil electrolyte. These relationships are the basis for developing techniques for improving regulatory and technical documents for metal pipelines, which are in conditions of low-cycle corrosion fatigue.

2. The joint use of the criteria of corrosion fatigue and criteria for corrosion monitoring of pipelines proposed in this paper [39] will allow to study in detail the mechanisms of propagation of corrosion fatigue cracks in underground metal pipelines in the area of corrosion fatigue, electrochemistry, surface physics, fracture mechanics and risk theory in aggressive environments.

3. The presented research results make it possible to predict the change in the corrosion state of the pipeline metal with time and to calculate the service life of local sections and the entire pipeline as a whole.

4. A mathematical model has been developed and the research results can be used by the organizations of Ukrtransgaz (structural subdivisions with the right of branches whose production facilities 
are located in all regions of Ukraine) [41] to solve problems related to the improvement of regulatory documentation for the protection of steel pipelines against corrosion and their technical diagnosis.

\section{References}

[1] DSTU-N B V.2.3-21:2008. Mahistral'ni truboprovody. Nastanova. Vyznachennya zalyshkovoyi mitsnosti mahistral'nykh truboprovodiv z defektamy (2008). Kyiv: Minrehionbud Ukrayiny.

[2] DSTU 4219-2003. Truboprovody stalevi mahistral'ni. Zahal'ni vymohy do zakhystu vid koroziyi (2003). Kyiv: Minrehionbud Ukrayiny, 72.

[3] DSTU B V.2.5-30:2006. Truboprovody stalevi pidzemni system kholodnoho i haryachoho vodopostachannya. Zahal'ni vymohy do zakhystu vid koroziyi (2006). Kyiv: Minbud Ukrayiny, 112.

[4] Petryna, Yu. D., Petryna, D. Yu., Kozak, O. L. (2012). Vplyv ekspluatatsiynykh chynnykiv na koroziyno-vtomne ruynuvannya staley mahistral'nykh naftohazoprovodiv. Rozvidka ta rozrobka naftovykh i hazovykh rodovyshch, 3 (44), 1-11. Available at: http://nbuv.gov.ua/UJRN/rrngr_2012_3_14

[5] Kiporenko, A. S. (2011). Sovershenstvovanie normativnogo obespecheniya ekspluatacionnoy bezopasnosti truboprovodnyh sistem atomnih elektrostanciy. Kharkiv: Ukrainskaya inzhenerno-pedagogicheskaya akademiya, 139.

[6] Anuchkin, M. P., Gorickiyb, V. N., Miroshnichenko, B. I. (1986). Truby dlya magistral'nyh truboprovodov. Moscow: Nedra, 232.

[7] Pohmurs'kiy, V. I,. Homa, M. S. (2008). Koroziyna vtoma metaliv ta splaviv. Lviv: Spolom, 152.

[8] Sangid, M. D. (2013). The physics of fatigue crack initiation. International Journal of Fatigue, 57, 58-72. doi: 10.1016/j.ijfatigue.2012.10.009

[9] Ray, A. (1999). Stochastic Modeling of Fatigue Crack Damage for Risk Analysis and Remaining Life Prediction. Journal of Dynamic Systems, Measurement, and Control, 121 (3), 386-393. doi: $10.1115 / 1.2802486$

[10] Pugno, N., Ciavarella, M., Cornetti, P., Carpinteri, A. (2006). A generalized Paris' law for fatigue crack growth. Journal of the Mechanics and Physics of Solids, 54 (7), 1333-1349. doi: 10.1016/ j.jmps.2006.01.007

[11] Dmytrakh, I. M., Panasyuk, V. V. (1999). Vplyv koroziynykh seredovyshch na lokal'ne ruynuvannya metaliv bilya kontsentratoriv napruzhen. Lviv: Redaktsiya zhurnalu "Fizyko-khimichna mekhanika materialiv", 340.

[12] Ratych, L. V. (1999). Anodic dissolution and hydrogen embrittlement contribution into corrosion-fatigue crack growth. Materials Science, 35 (3), 15-27.

[13] Ostash, O. P.; Panasuyk, V. V. (Ed.) (2015). Fracture mechanics and strength of materials. Vol. 15. Structure of materials and fatique life time of structural components. Lviv: Publishing House "SPOLOM", 312.

[14] Li, D. M., Nam, W. J., Lee, C. S. (1998). An Improvement on Prediction of Fatigue Crack Growth from Low Cycle Fatigue Properties. Engineering Fracture Mechanics, 60 (4), 397-406. doi: 10.1016/s00137944(98)00029-0

[15] Kaeshe, H. (1979). Die Korrosion der Metalle. Physikalisch-chemische Prinzipien und aktuelle Probleme. Berlin: Springer-Verlag, 400. doi: 10.1007/978-3-662-11502-2

[16] Morrow, J. (1950). Investigation of plastic strain energy as a criterion for finite fatigue life. The garret corporation report. Phaeniz, 105-108.

[17] Andreikiv, O. E., Lishchyns'ka, M. V. (1999). Equations of growth of fatigue cracks in inhomogeneous plates. Materials Science, 35 (3), 355-362. doi: 10.1007/bf02355479

[18] Li, Y. C., Huang, N. C. (1991). Fatigue crack speed of materials with linear hardening. International Journal of Solids and Structures, 27 (7), 865-883. doi: 10.1016/0020-7683(91)90021-7

[19] McMeeking, R. M. (1977). Finite deformation analysis of crack-tip opening in elastic-plastic materials and implications for fracture. Journal of the Mechanics and Physics of Solids, 25 (5), 357-381. doi: 10.1016/0022-5096(77)90003-5

[20] Panasyuk, V. V., Andreykiv, A. E., Parton, V. Z. (1988). Osnovy mekhaniki razrusheniya. Kyiv: Naukova dumka, 488.

[21] Valyashek, V. B., Kaplun, A. V., Yuzevych, V. M. (2015). Matematychne ta komp»yuterne modelyuvannya fizychnykh kharakterystyk materialu u vershyni trishchyny z urakhuvannyam efektu zmitsnen- 
nya. Kompyuterno-intehrovani tekhnolohiyi: osvita, nauka, vyrobnytstvo, 18, 97-104. Available at: http:// nbuv.gov.ua/UJRN/Kitonv_2015_18_18

[22] Chen, X., Mai, Y.-W. (2012). Fracture mechanics of electromagnetic mate-rials: nonlinear field theory and applications. New Jersey: Imperial College Press, 328. Available at: http://www.beck-shop.de/ fachbuch/leseprobe/9781848166639_Excerpt_001.pdf doi: 10.1142/p760

[23] Rice, J. R. (1968). A Path Independent Integral and the Approximate Analysis of Strain Concentration by Notches and Cracks. Journal of Applied Mechanics, 35 (2), 379-386. doi: 10.1115/1.3601206

[24] Manson, S. S., Halford, G. R. (1981). Practical implementation of the double linear damage rule and damage curve approach for treating cumulative fatigue damage. International Journal of Fracture, 17 (2), 169-192. doi: 10.1007/bf00053519

[25] Manson, S. S., Halford, G. R. (1986). Re-examination of cumulative fatigue damage analysis-an engineering perspective. Engineering Fracture Mechanics, 25 (5-6), 539-571. doi: 10.1016/00137944(86)90022-6

[26] Ellyin, F., Kujawski, D. (1986). An energy-based fatigue failure criterion. Microstructure and Mechanical Behaviour of Materials, 11, 591-601.

[27] Bol'shuhin, M. A., Zverev, D. L., Kaydalov, V. B., Korotkih, Yu. G. (2010). Ocenka dolgovechnosti konstrukcionnyh materialov pri sovmestnyh processah malociklovoy i mnogociklovoy ustalosti. Problemy prochnosti i plastichnosti, 72, 28-35.

[28] Desmorat, R. (2006). Damage and fatigue. Continuum damage mechanics modeling for fatigue of materials and structures. REGC. Geomechanics in energy production. Cachan, 10, 849-877. Available at: w3.lmt.ens-cachan.fr/PDFs/DESMORAT.2006.7.pdf

[29] Pichuhin, S. F., Zyma, O. Ye., Vynnykov, P. Yu. (2015). Nadiynist' liniynoyi chastyny pidzemnykh mahistral'nykh truboprovodiv. Zbirnyk naukovykh prats'. Seriya: haluzeve mashynobuduvannya, budivnytstvo. Poltava: PoltNTU, 1 (43), 17-28.

[30] Banabic, D. (2010). Plastic Behaviour of Sheet Metal. Sheet Metal Forming Processes. Berlin: Springer, 27-140. doi: 10.1007/978-3-540-88113-1_2

[31] Pakhalovych, M. (2017). Improving normative documents on the safe operation of the elements of pipeline systems of nuclear power plants beyond design term. Kharkiv, 24.

[32] Polyakov, S. H., Klymenko, A. V., Kovalenko, S. Yu. (2010). Systema koroziynoho monitorynhu truboprovodiv. Nauka ta innovatsiyi, 6 (5), 25-28.

[33] Dzhala, R. M., Verbenets, B. Y., Melnyk, M. I. (2016). Measuring of Electric Potentials for the Diagnostics of Corrosion Protection of the Metal Structures. Materials Science, 52 (1), 140-145. doi: 10.1007/ s11003-016-9936-y

[34] Akbashev, R. M., Zhulyaev, S. I., Kurdyumov, N. I. (2016). Prognozirovanie ostatochnogo sroka bezavariynoy sluzhby polyh metallicheskih obektov pod vliyaniem obshchey korrozii ih naruzhnoy poverhnosti pri provedenii ekspertizy promyshlennoy bezopasnosti. Nauka, tekhnika i obrazovanie, 3 (21), 124-126.

[35] Panchenko, S., Lavrukhin, O., Shapatina, O. (2017). Creating a qualimetric criterion for the generalized level of vehicle. Eastern-European Journal of Enterprise Technologies, 1 (3 (85)), 39-45. doi: 10.15587/1729-4061.2017.92203

[36] Gorbunov, D. V. (2014). Riski innovatsionnyih proektov i metodyi ih otsenki. Vektor nauki TGU, 3 (29), 123-126.

[37] Florescu, M. S. (2012). Analysis of economic risk in european investment projects. Revista Romana de Economie, 34 (1), 47-67. Available at: http://revecon.ro/articles/2012-1/2012-1-3.pdf

[38] Yuzevych, V. M., Klyuvak, O. V. (2015). Ekonomichnyy analiz rivniv efektyvnosti ta yakosti internet-platizhnykh system pidpryyemstva. Biznes Inform, 1, 160-164.

[39] Chaban, O. P., Yuzevych, L. M. (2015). Modelyuvannya ta yakist' monitorynhu diahnostychnykh system. Vymiryuval'na tekhnika ta metrolohiya, 76, 92-98.

[40] Chaban, O. P., Yuzevych, V. M. (2015). Matematychne modelyuvannya diahnostychnykh oznak dlya zabezpechennya systemy funktsionuvannya medychnykh posluh. Systemy obrobky informatsiyi, 2 (127), 108-113.

[41] Ofitsiynyi sayt PAT “UKRTRANS HAZ”. Available at: http:/utg.ua/utg/about-company/affiliates/ 